\title{
ANTIBACTERIAI AND IMMUNOLOGICAL EVALUATION OF GENTAMICIN AND SPECTINOMYCIN IN CHICKENS
}

\author{
Mohamed, T.A.; El-Nabtity, S.M. and Hendawy, A.A. \\ Department of Pharmacology, Faculty of Vet. Medicirle. Zagazig Universily \\ - Department of Zoolosty. Faeulıy of Science Zagazig Unlversily
}

\begin{abstract}
Tiwo hundreds and ten one day old hubbard chlcks were used in this study. They were divided into 6 groups. The first group was kept as control. The second group twas experimentally infected with $0.2 \mathrm{ml}$ of broth containing $10^{-8}$ C.F.U. of S. pullorum girien orally and left us positive control. The third group was experimentally infected ornlly urith S. pullorum and intramuscululy ivfected with gentamicin; $5 \mathrm{mg} / \mathrm{kg}$ b.ut for 5 siccessize dayss.

The fourth group was experincutally tujected twit/ $\mathrm{S}$ pullorum and injerted $1 / \mathrm{M}$ with spectinomycin $20 \mathrm{mg} / \mathrm{log}$ b.ut. twice with one day apart. The fifth grousp uas injesh.d I/M with gentamicin in the samke dose regimen, while sirtl group was I/M treated evith spectinomycin $20 \mathrm{ing} / \mathrm{kg}$ b.wt. twice twith one day apart. Non infected and gemtamicin treated birds demonstrated significant decrease in total proteins. Infected non trealed birds slwwel a significant increase in the total leuconytlc count and semm folat proteins. While treatment of infected bircls wilh spectionncin eliciled a signifiennt de'creose' in lotal l'ucocytic count. Non infected and spectinomycin treated birds divulgerd nor significant changes in the total letcoxytic counts. Both gentamicin and sprectinomycin exerted more inhibiton effect on $\mathrm{S}$ pullorsus compared with other aminoylycosides. collistin and tetracyclines but less polent compared with chloramphenirol and enroflox acin. It was conduded that ball gentanich \& spectmomycin dewid any significant of jects on chicken imunue system turned by S pulorum infection und high effiedacy of both drugss either in vivo or in vilto.
\end{abstract}

\section{INTRODUCTION}

The comsensus amongst the vetcrinary clindeians is that aminoglycostdes anc highly effective In trealmenl of discases caused mainly by gram ncfatlve bacteria (Sande and Mande1, 1985). Gentamicin has been proved as a broid speetrum andinoglycuslede, being supetior lhan oller 
conmunuly used antibiotics (Kurby \& Saniford, 1969).

In at like manner, high ellicacy of spectinomycin. with a number of propertes common with annogiyrosides. was evinced agininst colibacillosis \& Salmonclosis ln chickens (Hard1. 1973). Some clicmotherapcutics have inmunosuppressive cllect ellier by thetr abllity to inlerlcre with proleilı synthesis by pronoting rapld elemination ol antigens. or by intei feranec wilh plaggocylosis (Kruger, 1965).

The current study was carried out to evalualc the clficacy of both gentamich \& spectinony-

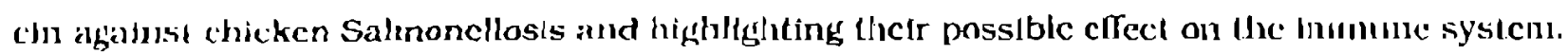

\section{MATERIAL AND METHODS}

\section{Drugs :}

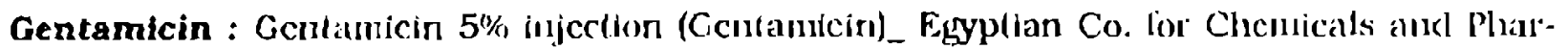
macenticals (ADWLA). Egypt.

Spectinomycin : Speclinonycin injertion (Speclam.)_ CEVA Abbot Co., Mance.

Experimental chicks :- Two lumdreds and ten heallhy, one day old hubbard broiler chleks

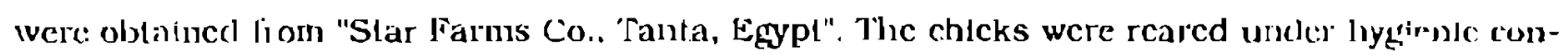
ditions and we fe fed on a balanced commerelal slarter poultry ration. At the age of 8 days they ivere dividied into 6 groups. Tlie lorly fluc chicks in the lìrst group recelved neillicr inlectlon nor medications (control). The Sixty chicks in the sccond group werc experlmentally infected orally with $0.2 \mathrm{ml}$ of broll conlaining $10^{8}$ C.l. .U. of $\mathbf{S}$ Dulloww (Heller \& Drabkin, 1977). The livenly Ave chicks in thled group were expcrimentally inlerled and after 2 days they wcic inlinumsculinly injectcel will gentanicin: $5 u$ g/kg b.ivt. for 5 successlve days (Greg \& Linda, 1986). 'Mic lventy tive chicks in (he fourtl gloup wcre experimentally lnfected and Intramuscularly injected witl sperlitionaycin: $20 \mathrm{mg} / \mathrm{kg}$.b.w1. Lwice will one day Interval (Nicholas \& Leslle, 1986).

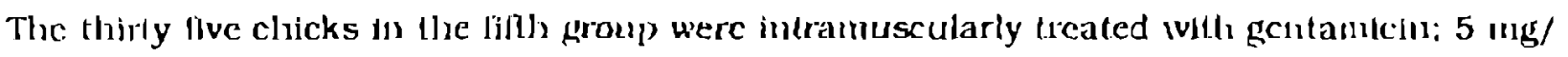

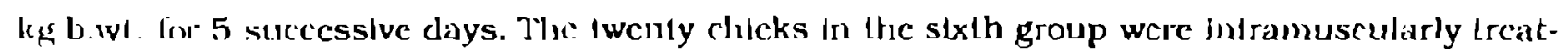
ed will sfyectinomycin. $20 \mathrm{mg} / \mathrm{kg}$ b.wt. Lw/ce with one day linterval .

Blood sampling :- Five blowel samples from each group were colleded after slanghtering on (he 1 st. $7^{\text {th }} .14^{\text {th }}$ and $21^{\text {st }}$ days post treatnent. Each sample was divided into two parts. The lirst parl : $5 \mathrm{ml}$ was Laken in clean, ury vals conlalntug EOTA to be used for the lolal leucocylic comıl (Natt \& Hexick, 1952) and difrerential counls (Schalm et al., 1975). the sccond part :(5ml) was laken withoul anticoagulant in stcrlle Wassciman tube for separalfon of scrum which is kcpl al - $20^{\circ} \mathrm{C}$ urill used lor estinlation of total scrun protelns (Welchselbaum, 1946) and ils 
fiatlions (Laemmli, 1970).

Antibacterial activity :-

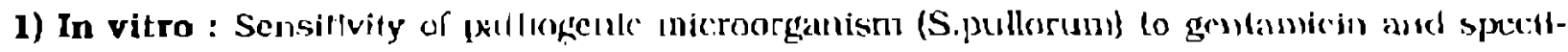

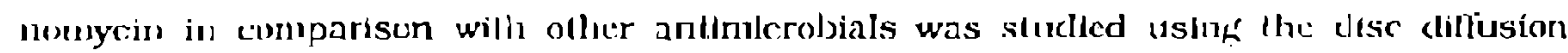
mulsud (Baser, 1863).

2) In vivo :- C.linical signs, P.M. linding's, mortality rate were recorded durilug the cxperiment.

- Statistical analysis : Dafa oblained uere stalistically analyscal using Student "l" test (Snedecor Cochran, 1967).

\section{RESULTS}

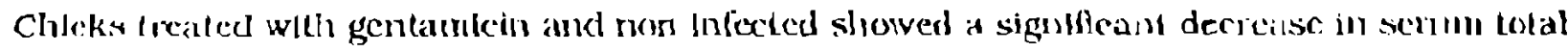
potcitss on the $2^{\text {nd }}$ and 3rd weck post teadment and a sigrilitiant decreass in scrum albumbs. a. is and s globulins in the $2^{\text {nd }} \& 3^{\text {rd }}$ ueck post treatnent (Table 1). Chicks infected will $S_{\text {. pul- }}$

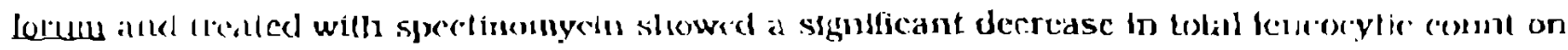

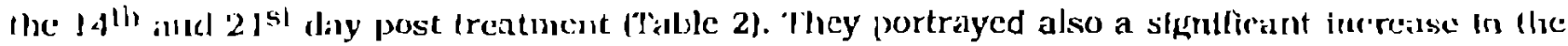

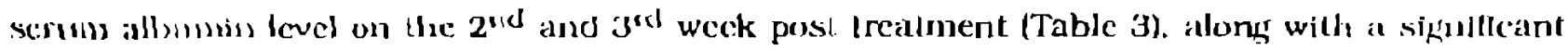
drerease in the serum a glolutin kevel on the $2^{\text {nd }}$ weck. Whesras senum s globulins fevel showed

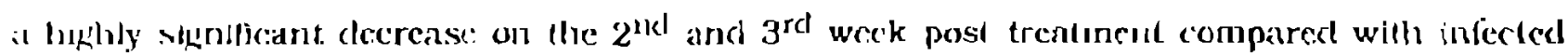
non treatcol\{tiadste 6\}.

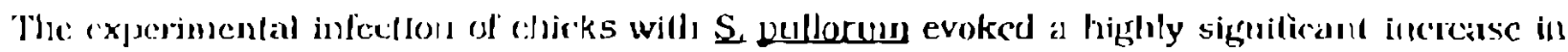

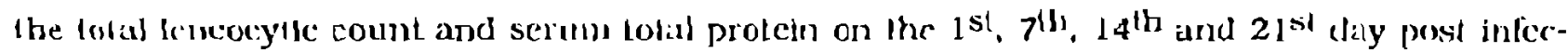
tion compalred wilh control group (Tible 4 \& 5 ). As well as a slgnilleant decrease in the serum albumin (liable 5). Serum a and s silobulin level demonslrated a highly significane increase. Sermm b) gilobribns level were non signifieandly allected trable I) .

Birds cxpentmenlilly infected with $\mathbf{S}$ pullowm and treated with fentamich demonstrated

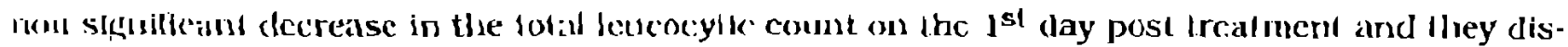
played a ligslyly significant decrealse on the $7^{\text {th }} .14^{\text {th }}$ and $21^{\text {sh }}$ day post treatment compared uill, infected. mon Ireated group (Table 4). 'Tley showed also) a decreascd tolal scrum protein on (hs $7^{\text {th }}$ \& $14^{\text {lll }}$ rlag post treatnent (Tablc, 5). They thusirated also a highly signilicint decrease in il

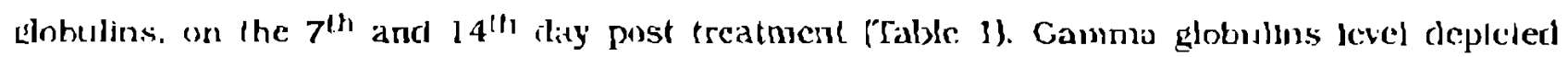
hifhly sifflifleant decrease on the $7^{11}, 14^{\text {th }}$ and $21^{\text {st }}$ day post treatulent conpared will the in-

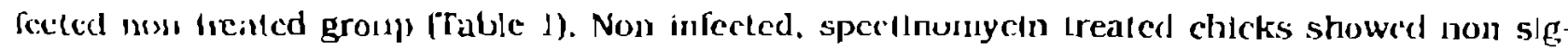
Inficant clatures in total serum proteins ind its fractions (Tables 3. 6) . 


\section{Antibacterial activity :}

1) In vitro: Goth gentamicin \& spectinomycln excited a more potcht inhlibitory cficet on S. pullortum compared with ollicr amlnoglyeosides, colisiln and tetracycllnes and less potent than chloramplacnicol and corohoxatin. In the same line, genlamicin has becn loumd to possiss a more potent hillibuy difect on S. pullown conpared with spectunomycin (ladble 71.

2) In vivo : Chicks experimentally inlcoted with $\$$. pullorum and non trealed displinyed chalacteristic clinical symptonas represcnled by dcpresslon. loss of appelitc, joor growth. dropped wings, rufled feallicis and whitish faeces covered vents .

Chicks inlected and trealed cilher by genlanucin or speet momycin showed milder degree ol (linteal symplonus compared with inlect exl. non treatcd.

Morially late was $15 \%$ in $\mathrm{S}$, pullorum inlected. nom trealed. On the other hand dealis were not recortech in other groups, Gross palhological lesions in non trealed blrds, experincntally inlected were enlarged \& congested liver. enterilis. pericardlus. colarged kidncys, spleen and

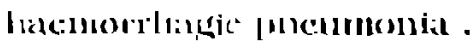

\section{DISCUSSION}

lit the prescul study, therc Iids becn bountalul evidence that healthy birds adninistored gen-

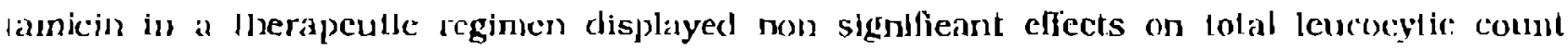
flurougluml the experimental period. Ou lindinges fil in with the results previously oblatined (Elchenworld, 1966). Who rceoreled that aminoglycosides failed to elicll signtfleant eflect on the leukogram in infants.

II lik leco shown that heallhy birds treated with therapeulle reglenen of gentamicin divulged a sigsilitant elcerease in the serum total protcins. albunnin, a, b and s globulins kevels on the $14^{\text {th }}$ and $21^{\text {st }}$ day post trealnient. No better evidence of the signifleant reduction in the serum lotal proteins, abbum and globulins levels can be eited than an alleged suppressive cflect of fentanicin on the humoral muntue response. The observed inhibition of mice imnunc response proved by clifferent doses of gentamicin, have suggested that a suppression of the lnmme sys-

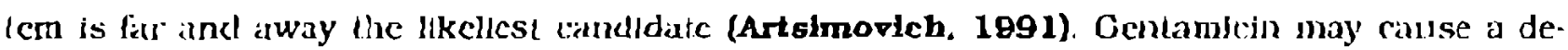
creasc in synthesis of plasma prolelns in liver and lead to appearance of profcin in large amounts in the urlnc (El-Deeb. 1995).

In the lince of absence of an anligen. that could he represented by Salmonella microorganisin in our sludy. a concelvable inmuno suppressive effect of gentamicin could be casily delceled. 
On the sime bisis (Exon et ad., 1989), stated that a possible immuno-suppressive crlect of genlimicin bitsed on the concept that the drug, In ligh doses, produces modest increase In the

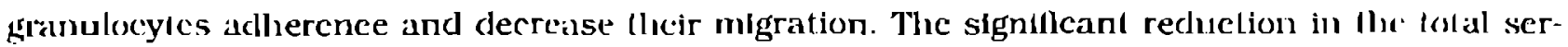
um proteins and Its liractlons is duc to the clicet of gentanich on both hepatic and renal cells Innclion. Our results coordinated with that previonsly repurted (Paghove et al., 1989 and Koesk et al., 1974). 'They reported degeneratlve changes in hepatic \& renai tissues.

It has been evideneed that, multiple oral administration of spectinomycin cvoked leucopenia in dogs' (Brown et al., 1990). In lact. (his apparent controversy could be best resulved in the

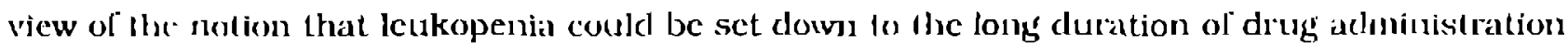
twhich may depress the granulupacisis In the bone marrow (Eisa, 1998).

Administration of spectinonyein in therapcutic reginen, evoked no signilicant effect on the leved of serum lotal proteins or any of ils fractions throughout the experincental period. Nearly similar results has becu previously reperted (Fathy, 1995). The author found wo alleridion in

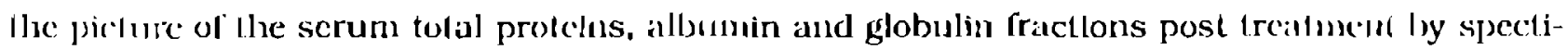
nonyein (20 mg/ $\mathrm{kg}$ b.wt.) twiec wilh one day interval in chickens.

Non trated chicks, experinentally infected wilh S. pullorun disclosed signilicant increase in the serum tolal proteins on the $1^{\text {st }}, 7^{\text {th }} \& 14^{\text {th }}$ day post treatment compared with control. lle as. signed the increase ia the serum lotal proteins to the increase of globulins level more than the ferrease in the albunin level in response to immumogen. Chicks experimentally inferted with $S$.

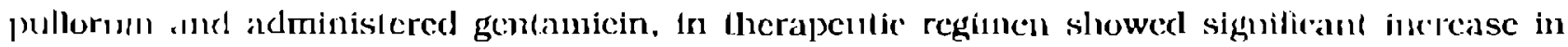

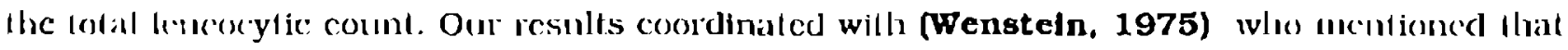
there were it signiljeant incease in tolal leucoeylic count and helerophils in chieks experinen.

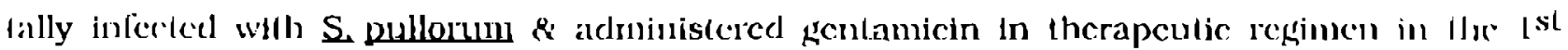
wock post-treatincnt.

Chicks experimentally infected will, $\mathrm{S}$ pullorum and tealed with the lherajeutic regimen ol

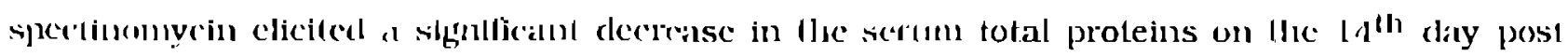
dealument vilh signilicant increase in the albumin level on the $14^{\text {th }} \& 21^{\text {st }}$ elay post treatment (Eisa, 1998). credited thls lindingss to the regencrative power of hepatic cells thal were recovered

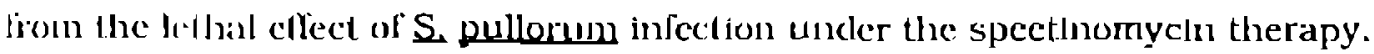

Both gentamicin \& spectinonverin exert a potent inhibitory ellect on S. pullorum either In viIro or in vivo. Our result were compalable with Olga et al. (1973). they staled that ferriming fiven via drinking waler or injection was effective in controlling Salınonella in chickens. Our onl. conle is lighly conmendabic by Smith \& Tueker (1975). The author recorded llat. sjucclinomycin in il dose level of $50 \mathrm{mg} / \mathrm{kg}$ b.wt. conlrols cmlelently S. typhimurlum infectlon in rhickens. 
Table 1 : Elfect of gentamicin in therapeulic regimen; $5 \mathrm{mg} / \mathrm{kg} . b . w t$. adminislered intramuscularly once a day for 5 successive days on the senum $a, b$ and $s$-globulins level ( $g m / d L)$ in both realthy and experimenlally S.pullorum inlected chicks. Mean \pm S.E. $n=5$.

\begin{tabular}{|c|c|c|c|c|c|}
\hline \multirow{2}{*}{ Group } & \multirow{2}{*}{$\frac{\text { c }}{\stackrel{0}{0}}$} & \multicolumn{4}{|c|}{ Time (post trealment) } \\
\hline & & $1^{5 l} \mathrm{day}$ & $7^{\text {th }}$ day & $14^{\text {th }}$ day & $21^{5 l}$ day \\
\hline \multirow{3}{*}{$\begin{array}{l}\text { Control (non-iniecled, non } \\
\text { treated) }\end{array}$} & $\alpha$ & $0.61 \pm 0.02$ & $0.64 \pm 0.01$ & $0.66 \pm 0.03$ & $0.69 \pm 0.01$ \\
\hline & $\beta$ & $0.73 \pm 0.01$ & $0.75 \pm 0.02$ & $0.80 \pm 0.01$ & $0.79 \pm 0.02$ \\
\hline & $\sigma$ & $0.43 \pm 0.01$ & $0.45 \pm 0.03$ & $0.41 \pm 0.02$ & $0.40 \pm 0.01$ \\
\hline \multirow{3}{*}{ Non infected + gentamicin } & $u$ & $0.59 \pm 0.02$ & $0.62 \pm 0.01$ & $0.55 \pm 0.02$ & $0.56 \pm 0.05$ \\
\hline & $\beta$ & $0.72 \pm 0.01$ & $0.72 \pm 0.02$ & $0.71 \pm 0.07^{*}$ & $0.70 \pm 0.03^{\circ}$ \\
\hline & $\sigma$ & $0.41 \pm 0.03$ & $0.44 \pm 0.01$ & $0.35 \pm 0.01^{\circ}$ & $0.33 \pm 0.02^{\circ}$ \\
\hline \multirow{3}{*}{ Infecled, non Ireated } & $a$ & $0.93 \pm 0.03^{\ldots}$ & $0.97 \pm 0.03$ & $0.97 \pm 0.02^{4 k t}$ & $\overline{0.98} \pm 0.03 \cdots$ \\
\hline & $\beta$ & $0.74 \pm 0.02$ & $0.74 \pm 0.03$ & $0 . \overline{71} \pm 0.06$ & $0.70 \pm 0.06$ \\
\hline & $\sigma$ & $0.86 \pm 0.03^{* \cdots}$ & $0.98 \pm 0.05 * * *$ & $0.88 \pm 0.05^{* \cdots}$ & $0.72 \pm 0.02 \cdots$ \\
\hline \multirow{3}{*}{ Inlecled + genlamicin } & $\alpha$ & $0.91 \pm 0.03$ & $0.71 \pm 0.05++$ & $0.76 \pm 0.04++$ & $0.69 \pm 0.04$ \\
\hline & $\beta$ & $0.70 \pm 0.03$ & $0.76 \pm 0.02$ & $0.82 \pm 0.01$ & $0.74 \pm 0.02$ \\
\hline & $\sigma$ & $0.85 \pm 0.03$ & $0.72 \pm 0.03++$ & $0.68 \pm 0.02^{++}$ & $0.50 \pm 0.04^{++}$ \\
\hline
\end{tabular}

- $P<0.05$

(' Compared with the control group)
(+ Compared with ine inlecled non trealed group)

Table 2 : Effecl of spectinomycin in therapeutic regimen; $20 \mathrm{mg} / \mathrm{kg} . b . w t$. adminisered intramuscularly twice with one day interval on the tolal leucocytic counls ( $X 103$ cels $/ \mathrm{mm} 3$ ) in bolh healthy and experimentally S. pullorum inlected chicks. Mcan \pm S.E. $\quad \pi=5$

\begin{tabular}{|c|c|c|c|c|}
\hline \multirow{2}{*}{ Group } & \multicolumn{4}{|c|}{ Time (post treaiment) } \\
\hline & $1^{\text {st day }}$ & $7^{\text {th }}$ day & $14^{\text {th }}$ day & $21^{\text {sl }}$ day \\
\hline control (non-inlccled, non treated) & $30.30 \pm 0.30$ & $30.60 \pm 0.99$ & $31.80 \pm 0.70$ & $32.10 \pm 0.94$ \\
\hline non inlecled + spectinomycin & $30.50 \pm 0.69$ & $30.30 \pm 0.78$ & $31.00 \pm 0.35$ & $31.70 \pm 0.41$ \\
\hline $\begin{array}{l}\text { infecled, non trealed } \\
\text { inlected + specti-no-mycin }\end{array}$ & $\begin{array}{c}52.90 \pm 1.03^{\cdots \cdots} \\
52.10 \pm 0.70\end{array}$ & $\begin{array}{c}55.20 \pm 1.08 \cdots \\
54.30 \pm 1.06\end{array}$ & $\begin{array}{l}56.10 \pm 0.60^{2+} \\
49.80_{ \pm 0.75^{+++}}\end{array}$ & $\begin{array}{l}46.60 \pm 0.80^{\cdots} \\
40.80 \pm 1.12^{++}\end{array}$ \\
\hline
\end{tabular}

- $P<0.05$

$\therefore P<0.01$

$\cdots P<0.001$

(- Compared wilh the conlrol group)

(+ Compared with the inlecled non treated geoup) 
Table 3 : Eflect of spectinomycin in therapeulic regimen; $20 \mathrm{mg} / \mathrm{kg} \cdot b . w t$. adminislered irliarluuscularly twice with one day inlerval on the serum tolal proleins level and the Serum albuınıt level $(\mathrm{gm} /$ $\mathrm{dL}$ ) in both heallhy and experimenlally S.pullorum inlecled chicks. Mean \pm S.E. $n=5$.

\begin{tabular}{|c|c|c|c|c|c|}
\hline \multirow{2}{*}{ Group } & \multirow[b]{2}{*}{ Serum } & \multicolumn{4}{|c|}{ Time (post treatment) } \\
\hline & & $1^{\text {sl }}$ day & $7^{\text {th }}$ day & $14^{\text {th }}$ day & $21^{51}$ day \\
\hline \multirow[t]{2}{*}{$\begin{array}{l}\text { Control (norrinlected, } \\
\text { non treated) }\end{array}$} & $\begin{array}{l}\text { Tolal } \\
\text { proteins }\end{array}$ & $4.10 \pm 0.05$ & $4.20 \pm 0.05$ & $4.50 \pm 0.09$ & $4.30 \pm 006$ \\
\hline & Albumin & $2.28 \pm 0.09$ & $2.30 \pm 0.10$ & $2.46 \pm 0.16$ & $2.34 \pm 0.07$ \\
\hline \multirow[t]{2}{*}{$\begin{array}{l}\text { non inlecled + specti- } \\
\text { nomycin }\end{array}$} & $\begin{array}{l}\text { Total } \\
\text { proteins }\end{array}$ & $3.94 \pm 0.18$ & $4.30 \pm 0.09$ & $4.40 \pm 0.09$ & $4.20 \pm 011$ \\
\hline & Albumin & $2.13 \pm 0.08$ & $2.40 \pm 0.11$ & $2.44 \pm 0.19$ & $2.35 \pm 0.07$ \\
\hline \multirow[t]{2}{*}{ Inlected, non treated } & $\begin{array}{l}\text { Tolal } \\
\text { proteins }\end{array}$ & $4.46 \pm 0.08^{\cdots}$ & $4.49 \pm 0.06^{\star *}$ & $4.80 \pm 0.05^{\circ}$ & $4.60 \pm 0.04^{\cdots}$ \\
\hline & Albumin & $1.96 \pm 0.08^{\circ}$ & $2.00 \pm 0.06^{-}$ & $2.00 \pm 0.07^{\circ}$ & $2.05 \pm 006^{\circ}$ \\
\hline \multirow[t]{2}{*}{$\begin{array}{l}\text { Inlected + spectinom- } \\
\text { ycin }\end{array}$} & $\begin{array}{l}\text { Tolal } \\
\text { proleins }\end{array}$ & $4.36 \pm 0.09$ & $4.42 \pm 0.10$ & $4.60 \pm 0.07^{+}$ & $4.37 \pm 0.07$ \\
\hline & Albumin & $1.90 \pm 0.09$ & $1.92 \pm 0.05$ & $2.20 \pm 0.02+$ & $2.25 \pm 0.04^{+}$ \\
\hline
\end{tabular}

$\cdot p<0.05$ $\because p<0.01$

(" Compared wilh the control group)

( + Compared with the inlected non trealed group)

Table 4: Eflecl of genlamicin in therapeutic regimen; $5 \mathrm{mg} / \mathrm{kg}$.b.wt. administered intramuscularly once a day lor 5 successive days on the lotal leucocylic counls (X 103 cells $/ \mathrm{mm} 3$ ) in both healthy and experimentally S. pullorum infecled chicks. Mean + S.E. $n=5$.

\begin{tabular}{|c|c|c|c|c|}
\hline \multirow{2}{*}{ Group } & \multicolumn{4}{|c|}{ Time (post treatmont) } \\
\hline & $1^{\text {st }}$ day & $7^{\text {th }}$ day & $14^{\text {th }}$ day & $21^{\text {st }}$ day \\
\hline control (non-inlected, non treated) & $30.70 \pm 0.34$ & $31.20 \pm 0.46$ & $31.40 \pm 1.13$ & $30.20 \pm 1.08$ \\
\hline non infecled + gentamicin & $30.90 \pm 0.29$ & $31.10 \pm 0.60$ & $30.20 \pm 1.01$ & $29.00 \pm 0.82$ \\
\hline Infecled, non trealcd & $55.30 \pm 1.10^{\cdots}$ & $55.50 \pm 0.55^{\cdots}$ & $57.30 \pm 0.51 \cdots$ & $47.20 \pm 0.72 \cdots$ \\
\hline Inlected + gentamicin & $54.50 \pm 0.63$ & $50.80 \pm 0.34^{t++}$ & $46.90 \pm 0.64^{+t+}$ & $37.80 \pm 0.82^{+++}$ \\
\hline
\end{tabular}

$\because p<0.001 \quad$ (" Compared with ine conirol group)

( + Compared with the inlected non trealed group) 
Table 5: Effect of Gentamicin in therapeulic regimen; $5 \mathrm{mg} / \mathrm{kg} . \mathrm{b} . w \mathrm{w}$. adminislered intramuscularly once a day for 5 successive days on the Serum lotal proteins level and serum albumin level $(\mathrm{gm} /$ $\mathrm{dL}$ ) in both healthy and experimenlally S, pullorum inlecled chicks. Mean + S.E. $n=5$.

\begin{tabular}{|c|c|c|c|c|c|}
\hline \multirow{2}{*}{ Group } & \multirow{2}{*}{ Serum } & \multicolumn{4}{|c|}{ Time (post treatment) } \\
\hline & & $1^{\text {st }}$ day & $7^{\text {th }}$ day & $14^{\text {th }}$ day & $21^{\text {st day }}$ \\
\hline \multirow[t]{2}{*}{$\begin{array}{l}\text { Control (non-intected, } \\
\text { non trealed) }\end{array}$} & $\begin{array}{l}\text { Tolal } \\
\text { proteins }\end{array}$ & $3.90 \pm 0.17$ & $4.00 \pm 0.09$ & $4.20 \pm 0.13$ & $4.10 \pm 0.07$ \\
\hline & Albumin & $2.13 \pm 0.04$ & $2.16 \pm 0.06$ & $2.33 \pm 0.10$ & $2.22 \pm 0.08$ \\
\hline \multirow[t]{2}{*}{$\begin{array}{l}\text { Non infected + } \\
\text { genlamicin }\end{array}$} & $\begin{array}{l}\text { Total } \\
\text { proteins }\end{array}$ & $3.80 \pm 0.17$ & $3.90 \pm 0.09$ & $3.65 \pm 0.17^{\circ}$ & $3.53 \pm 0.18^{\circ}$ \\
\hline & Albumin & $2.07 \pm 0.04$ & $2.11 \pm 0.03$ & $2.01 \pm 0.08^{\circ}$ & $1.93 \pm 0.09^{\circ}$ \\
\hline \multirow[t]{2}{*}{$\begin{array}{l}\text { Inlecled, non } \\
\text { treated }\end{array}$} & $\begin{array}{l}\text { Total } \\
\text { proteins }\end{array}$ & $4.48 \pm 0.09^{\prime \prime}$ & $4.65 \pm 0.19^{*}$ & $4.55 \pm 0.07^{\circ}$ & $4.35 \pm 0.15$ \\
\hline & Albumin & $1.95 \pm 0.05^{\circ}$ & $1.91 \pm 0.07^{*}$ & $2.00 \pm 0.05^{\circ}$ & $2.11 \pm 0.04$ \\
\hline \multirow[t]{2}{*}{ Inlected + gentamicin } & $\begin{array}{l}\text { Total } \\
\text { proteins }\end{array}$ & $4.40 \pm 0.23$ & $4.12 \pm 0.07^{+}$ & $4.30 \pm 0.08+$ & $4.09 \pm 0.09$ \\
\hline & Albumin & $1.94 \pm 0.07$ & $1.90 \pm 0.06$ & $1.98 \pm 0.04$ & $2.10 \pm 0.07$ \\
\hline
\end{tabular}

$\cdot P<0.05$

(' Compared with the control group)

$\{+$ Compared with the infected non trealed group $\}$ 
Table 6 : Ellect of speclinomycin in therapeulic regimen; $20 \mathrm{mg} / \mathrm{kg} . \mathrm{b} . \mathrm{wt}$. administered Imiramuscularly Iwice with one day inlerval on the serum $\mathbf{a}, \mathbf{b}$ and 5 -globulins level $(\mathrm{gm} / \mathrm{dL})$ in both healthy and experımentally S.pullorum infecled chicks. Mean + S.E. $n=5$.

\begin{tabular}{|c|c|c|c|c|c|}
\hline \multirow{2}{*}{ Gral. } & \multirow{2}{*}{$\stackrel{\check{g}}{\overline{\overparen{e}}}$} & \multicolumn{4}{|c|}{ Time (poss treatment) } \\
\hline & & $1^{51}$ day & $7^{\text {th }}$ day & $14^{\text {th }}$ day & $21^{\text {sl }}$ day \\
\hline \multirow{3}{*}{$\begin{array}{l}\text { Control (non-inlected, non } \\
\text { Ireated) }\end{array}$} & $\alpha$ & $0.63 \pm 0.02$ & $0.69 \pm 0.02$ & $0.71 \pm 0.01$ & $0.69 \pm 0.04$ \\
\hline & $\beta$ & $0.77 \pm 0.02$ & $0.74 \pm 0.02$ & $0.89 \pm 0.03$ & $0.88 \pm 0.03$ \\
\hline & $\sigma$ & $0.42 \pm 0.02$ & $0.47 \pm 0.02$ & $0.44 \pm 0.05$ & $\overline{0.39 \pm 0.01}$ \\
\hline \multirow{3}{*}{$\begin{array}{l}\text { non inlected + spectinom- } \\
\text { ycin }\end{array}$} & $\alpha$ & $0.64 \pm 0.03$ & $0.70 \pm 0.02$ & $0 . \overline{70 \pm 0.03}$ & $0.65 \pm 0.04$ \\
\hline & $\beta$ & $0.74 \pm 0.02$ & $0.75 \pm 0.01$ & $0.85 \pm 0.04$ & $0.84 \pm 0.05$ \\
\hline & $\sigma$ & $0.43 \pm 0.02$ & $0.45 \pm 0.02$ & $0.41 \pm 0.04$ & $0.36 \pm 0.03$ \\
\hline \multirow[t]{3}{*}{ Infected . ron trealed } & $\alpha$ & $0.94 \pm 0.01^{\ldots}$ & $0.91 \pm 0.02^{* \star *}$ & $0.90 \pm 0.02^{\cdots}$ & $0.80 \pm 0.04$ \\
\hline & $\beta$ & $0.78 \pm 0.03$ & $0.77 \pm 0.01$ & $0 . \overline{95} \pm 0.02$ & $0.90 \pm 0.04$ \\
\hline & $\sigma$ & $0.80 \pm 0.03 \cdots$ & $0.82 \pm 0.04^{* \ldots *}$ & $0.87 \pm 0.02^{* 4}$ & $0.70 \pm 0.02^{\cdots}$ \\
\hline \multirow[t]{3}{*}{ Infected + spectinomycin } & $\alpha$ & $0.91 \pm 0.04$ & $0.88 \pm 0.01$ & $0.79 \pm 0.01^{++}$ & $0.73 \pm 0.03$ \\
\hline & $\beta$ & $0.76 \pm 0.01$ & $0.80 \pm 0.03$ & $0.90 \pm 0.05$ & $0.89 \pm 0.02$ \\
\hline & $\bar{\sigma}$ & $0.79 \pm 0.01$ & $0.78 \pm 0.01$ & $0.72 \pm 0.04^{++}$ & $0.50 \pm 0.03^{++}$ \\
\hline
\end{tabular}

- $P<0.05$

-. $P<0.01$

$\cdots P<0.001$

(" Compared wilh the control group)

(+ Compared with the inlected non Ireated group)

Table 7 : Sensitivity of S. pullorum to gentamicin and spectinomycin in comparison with some antımıcrobial agents. Mean \pm SE. $(n=5)$.

\begin{tabular}{|l|c|c|c|}
\hline Antimicroblal agents dlscs & Mark & $\begin{array}{c}\text { Polency of } \\
\text { disc (ug) }\end{array}$ & $\begin{array}{c}\text { Inhibition zone diameter in } \\
\text { (mm) }\end{array}$ \\
\hline Chloramphenicol & $\mathrm{C}$ & 30 & $22.4 \pm 0.2$ \\
Colistin & $\mathrm{CL}$ & 25 & $12 \pm 0.12$ \\
Enrolloxacin & Enr. & 5 & $28.7 \pm 0.31$ \\
Gentamicin & $\mathrm{GN}$ & 10 & $18.55 \pm 0.11$ \\
Neomycin & $\mathrm{N}$ & 10 & $10.91 \pm 0.15$ \\
Spectinumycin & $\mathrm{SH}$ & 25 & $16.01 \pm 0.5$ \\
Streptomycin & $\mathrm{S}$ & 10 & $13 \pm 0.22$ \\
Tetracyclines & $\mathrm{TE}$ & 30 & $14.1 \pm 0.25$ \\
Toblamycin & Tob. & 10 & $14.31 \pm 0.31$ \\
\hline
\end{tabular}




\section{REFERENCES}

Artsimovich N. G. (1991) : Study of the immunolsopic activity of aminoglycoside illtilsiot k: Anllblot. Khimiother.. $36(2): 27$.

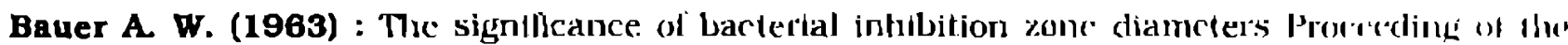
3rd Intemallonal Congress of Chemolherapy. Shivtigart.

Brown S. A. Cooper J., Gavze J. J., Greco D. S., Weise D. W. and Buck J. M. (1990) : |'|al|macokinclics of spectinomych in dogs alter single intravenous and multiple wall aldministration of the drug. An. J. Vet. Res., 51 (7) : 1056.

Elchenworld H. F. \{1966) : Some observations on dosage and loxicity of kamanturein in prithliturc and lull term infants. An. N. Y. Acad. Sci. 132 : 984.

Elsa A. A. (1998) : Clfncopathological studics on some antidiarrhocal clrugs' in rabbjils. M.V.Sil. Thesis. Farulty of Vel. Med.. Zagazig Univ.

El-Deeb A. Kh. (1995) : Clinicopathological studles on some diug interactions in allsine rills. M.V.Se. Thesis, Faculty of Vrt. Mediclne Zagazig Untversily.

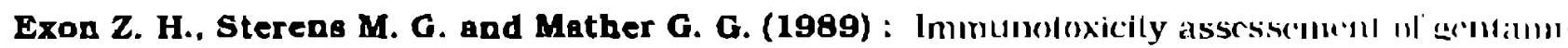
cin. Vel. Hum. Toxicol., 3」(5): 427.

Fathy M. E. (1995) : Infeuence of spectiomycin immunily of vaccillated clucks M.V.is. "Tlu'sis. l'aculty of Vet. Med. Zagazig Univ.

Greg J. H. D. and LInda R. H. B. (1986) : Pel birds renal discase. Clinical Nibun Meclucine ,uncl Surgery, W.B. Saunders Co., Philaclelphla, London 527.

Hardi H. (1973) : SpectInomycin In Vetertnary l'raclice Velcrinary Rccorcl. 92. 5: 12:3.

Heller E. D. and Drabkla N. (1977) : Some characleristics of Pathogenic E.coli sllamis [H. VAl. J. 1:1:1: 572

Klrby W. M. M. and Sanbord H. C. (1969) : Gellamicin In vitro Studies J. Intect. [Dis. I l(1. :36il.

Koesk J. C., Mazze R. 1. and Cousine M. J. (1974) : Nephroloxicily of gentambent. Lath. lawist. $30: 48$.

Kruger R. G. (1965) : The effeet of amlnoglycosides (streptomycin] on antibody syntlesis III vitro. Proc. Natl. Acad. Sci. U. S.A., 54: 144- 152.

Laemmll U. K. (1970) : Structural proteins during the assenubly of the hadel of IJinterioplanke. Nalui'c. 227 (15) : 680.

Natt M. P. and Herlek C. A. (1952) : A new blood dilvuent lor counting Her crylloreveres and 
leucocyles of chickens Pnult. Si:l. $31: 735$.

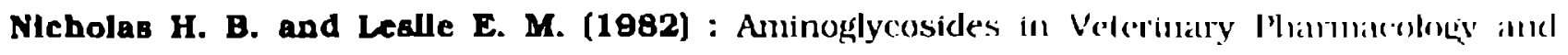
Therapeutics. 5th ed., 751. lowa Stalc. University Press AMES. IOWA.

Olga M. O., Snoegenbos G. H. and Smyser C. F. (1973) : Chemolherapeutic stuclies ul sillum). nella typhimurlum in chlckens. Avian Dis., 14, 379.

Pashore D.. Lasher L. and Diakov L. (1987) : Subchronic toxicily of aprantyrur. Vill. Mirl. Nilll. kl, $24(7): 37$.

Sande M. A and Mandel G. L. (1985) : The aninoglycosteles. In Gilmann. A. (;. and (inmlm,m L.S. (cd.). The Pharmacological Basis of Therapcutics 6th rd. New York. Millimllim. 1150.

Schalm. O. W.: Jaim, N.C. and Carroll, E. J. (1975) : The aumoglycoside's. In Cilluilı. A. (i. Goodman. L.S. (ed.). The pharmacological Basis and Themapenlies New Huls. Matruil. lan. Gth ed. 1150.

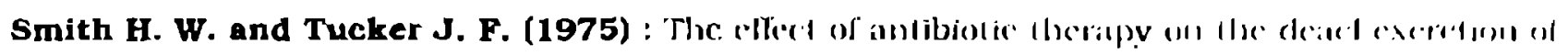
salmonella tyophimurium by expermentally mlected ehickens J. HyL. 75/221:275.

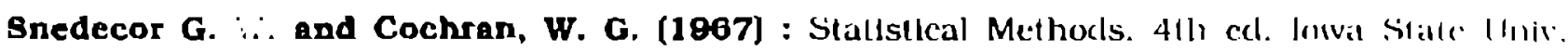
Press. Nuncs lliciapcitics. New York, Macmillan, 5llr ecl. 1167. 


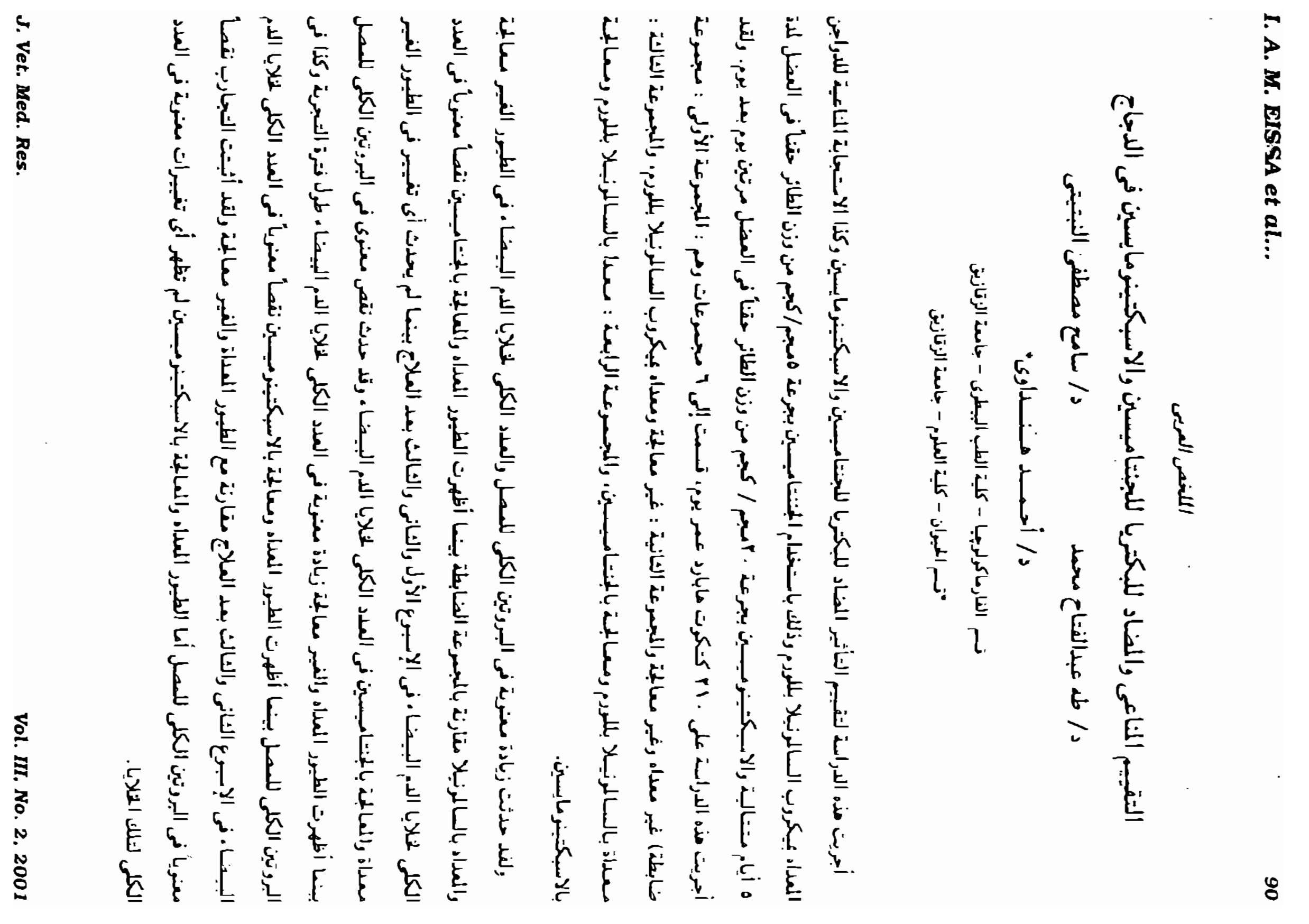


كسا أظهرت النسانج أن لعقارى الجنتاميسين والاكبكتينومايسين تأثبرأ ميزا وفعالاً ضد ميكروب السالمرنبلا بللورم

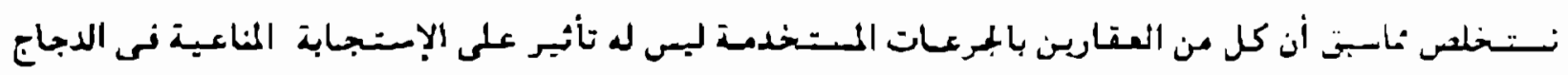

المعد5. 